\title{
Measuring and Promoting Entrepreneurial Intentions and Entrepreneurial Competence - Implications for Education
}

\author{
Johann Faltermeier, ${ }^{1, *}$ \\ ${ }^{1}$ ibi research an der Universität Regensburg GmbH, Galgenbergstraße 25, 93053 Regensburg, Germany
}

\begin{abstract}
The questionnaire "Entrepreneurial Competence" (developed as part of the author's dissertation) can be used in practice, but above all also for the measurement of entrepreneurial intentions and competence within (higher) education. Data were collected in two periods at both universities, OTH Regensburg and VŠTE Budweis, for the underlying descriptive evaluation in the field of higher education. This study provides information on the entrepreneurial environment, but also on the students' entrepreneurial competence. At the two universities, 153 students have already taken part in an entrepreneurship course. The environment at both institutes is rated as above-average. The entrepreneurial intention is also clearly visible at the institutes and is significantly higher in the second survey. In the area of entrepreneurial knowledge and skills, the second survey revealed higher levels than at the time of the first initial measurement. In order to be able to better adapt the teaching to the entrepreneurial intentions and entrepreneurial competence of students in the future, the increasing use of activating elements within entrepreneurship and intrapreneurship education is recommended. Planning, role-play, case studies and project work, for instance, contribute to the targeted, group-specific and differentiated competence-based promotion of potential entrepreneurs and intrapreneurs. To achieve this, the initial measurement of entrepreneurial intentions and entrepreneurial competence is therefore essential.
\end{abstract}

Keywords: entrepreneurial competence; entrepreneurial education; entrepreneurship; intrapreneurship

\section{Introduction}

At the heart of entrepreneurial intentions and entrepreneurial competence is the conflict between entrepreneurship and intrapreneurship. "Entrepreneurial Intention" describes the intention to create an (innovative) company, while "Intrapreneurial Intention" is defined as the intention to create a quasi-independent, innovation-capable collaboration within an existing organization. Intrapreneurship, as a field of research, has been gaining traction since the 1980s and is based on the work of Pinchot [1-2], Hisrich [3] and Bitzer [4]. The measurement of the entrepreneurial intentions and entrepreneurial competence of the students at the Ostbayerische Technische Hochschule (OTH) Regensburg and the Technische und Ökonomische Hochschule in Budweis (VŠTE), as described herein, was carried out with the help of a database generated using a strategic instrument. The questionnaire method was applied to determine the entrepreneurial intentions, as well as the (cognitive) psychological aspects of entrepreneurial competence. For this purpose, the questionnaire "Entrepreneurial Competence", which was developed as part of the dissertation "Der Unternehmer in uns - Entwicklung einer Diagnostik der unternehmerischen Absichten zur Förderung der unternehmerischen Kompetenz im Entre- und Intrapreneuership" ("The entrepreneur within us - development of a diagnostic tool for entrepreneurial intentions to promote entrepreneurial competence in entrepreneurship and intrapreneurship"), was used. This was included in a large-scale study. The following spot checks, as well as all the results, are taken from the pre-test for this study, which was conducted in March 2017. In addition, a second survey was carried out using the questionnaire in August 2019 in order to better assess the impact of entrepreneurship education at both institutes over a period of two years. This contribution is the first to examine and interpret the results of the two study periods with regards to entrepreneurship education.

To date, direct comparisons between entrepreneurial and intrapreneurial intentions with regards to entrepreneurial skills and knowledge have not been the focus of much scientific work. Rather, it is often assumed that "internal and external entrepreneurship [. . .] is not fundamentally [different], at least not in terms of their peculiarities and behavioral characteristics" [5, p. 23 f.]. What kinds of qualities, skills, abilities, as well as forms of knowledge are relevant for entrepreneurs and intrapreneurs? In order to answer this question, it is first worth looking at the definition and systematization of entrepreneurial competence.

Entrepreneurial competence is one of eight key competences in the European Framework of Reference [6]. This competence can be defined as "the ability of the individual to put ideas into practice. This requires creativity, innovation

\footnotetext{
* Corresponding author: johann.faltermeier@ibi.de
} 
and risk-taking, as well as the ability to plan and implement projects to achieve specific aims. Entrepreneurial competence helps the individual not only in their daily life at home or in society, but also at work [...]; it is the basis for [...] a social or commercial activity" [6, p. 11]. According to this, entrepreneurial competence is an everyday competence that can be highly relevant in the private as well as professional context. Systemically, entrepreneurial competence can first be understood as a bundle of skills and methodological knowledge, job-specific abilities and skills. This is characterized by the fact that it can be learned, changed, trained or improved in a short period of time by means of initial and further training. Knowledge and skills are referred to in research as cognitive aspects of entrepreneurial competence. This bundle is extended by psychological conditional factors, more precisely by abilities and qualities (aptitudes), which have little or no influence on the quality of a person's life. These psychological conditional factors can be changed in the long term through experience and training, i.e. they are relatively stable in time and situation [7-9].

\section{Methodology}

The conceptual research model is based on the findings of Ajzen [10-14], as well as on other modified models of the theory of planned behavior [15-18]. In order to be able to derive implications for teaching, a model oriented towards entrepreneurship education is already recommended here. This model, which sees entrepreneurship education as, among other things, a direct influential variable of intentions, is provided by Rauch and Hulsink [19]. These intentions, in turn, serve as a regressor of entrepreneurial behavior (cf. Figure 1).

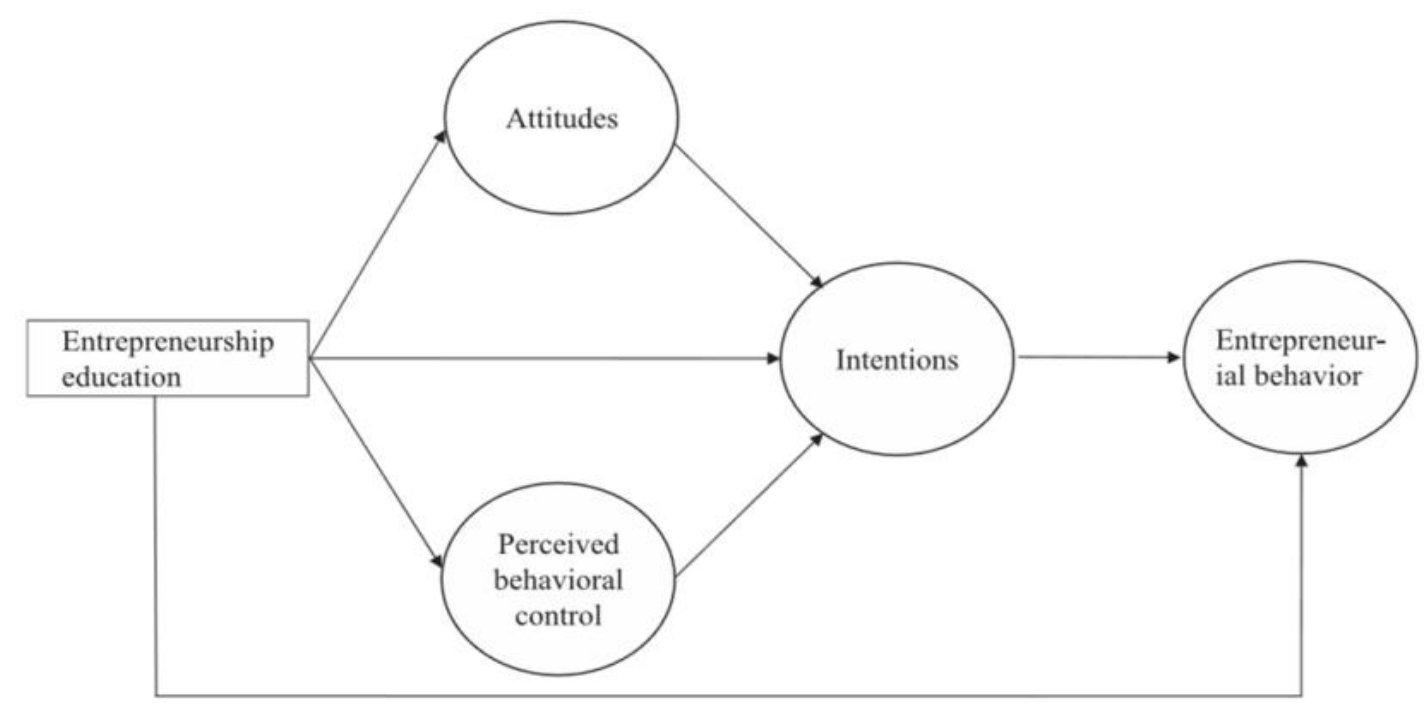

Figure 1. Theory of planned behavior

Source: Rauch \& Hulsink, 2015, modified.

Intentions depend on personal aspects, e.g. attitudes towards entrepreneurial behavior. The determinant of perceived behavioral control, i.e. an individual's assessment of how easy or difficult it is to carry out intentional behavior, also provides evidence that entrepreneurial characteristics, but also, for example, entrepreneurial knowledge, have a significant influence on entrepreneurial behavior [11-13, 19]. However, the exact composition of the heterogeneous learning groups is often not known in teaching. In order to find out the learners' intentions and entrepreneurial skills, it is advisable to take an initial measurement of these aspects.

The "Entrepreneurial Competence" questionnaire consists of individual instruments, which serve to measure entrepreneurial competence, differentiated according to entrepreneurial intentions. To capture entrepreneurial intentions in a context-based manner, tools are selected for the desired occupation and types of intention (metric). These are partly transferred from existing surveys, such as the Global University Entrepreneurial Spirit Students' Survey (GUESSS), and are supplemented by own items, in particular for intrapreneurial intentions [20]. Tested and proved scales and items are used for recording cognitive and psychological aspects of entrepreneurial competence, e.g. for personality ("Big Five Inventory") [21]. Mostly nominal and interval scales (7-point Likert scales) are used. The data were collected as part of the project "Entrepreneurial skills on the Czech-Bavarian labour market at the Eastern Bavarian Institute of Technology (OTH) Regensburg and at the Institute of Technology and Business in Budweis (VŠTE)".

The spot check consists of 132 valid data sets for the first survey and 281 valid data sets for the second survey at both institutes. A total of 413 students - 224 students from OTH Regensburg and 189 students from VŠTE Budweis participated successfully in the surveys. All students provided information on their age, with 412 students also providing information about their gender. For the first and second surveys, the spot check consisted of a total of 301 students in the age group $18-24$ years, followed by $25-34$ years $(n=77)$ and people older than 35 years $(n=35) .270$ female and 142 
male students took part in the survey. The following table summarizes the demographic data on age and gender according to institute and study period (cf. Tables 1 and 2).

Table 1. Age of participants

\begin{tabular}{|l|l|c|c|c|c|}
\hline Institute & Time of data collection & $\mathbf{1 8 - 2 4}$ years & $\mathbf{2 5 - 3 4}$ years & $\begin{array}{c}\text { 35 years and } \\
\text { older }\end{array}$ & Total \\
\hline OTH Regensburg & First data collection & 40 & 15 & 1 & 56 \\
\hline & Second data collection & 122 & 43 & 3 & 168 \\
\hline VŠTE Budweis & First data collection & 72 & 4 & 0 & 76 \\
\hline & Second data collection & 67 & 15 & 31 & 113 \\
\hline & Total & 301 & 77 & 35 & 413 \\
\hline
\end{tabular}

Source: Author.

Table 2. Gender distribution of participants

\begin{tabular}{|l|l|c|c|c|}
\hline Institute & Time of data collection & Female & Male & Total \\
\hline OTH Regensburg & First data collection & 40 & 16 & 56 \\
\hline & Second data collection & 103 & 64 & 167 \\
\hline VŠTE Budweis & First data collection & 48 & 28 & 76 \\
\hline & Second data collection & 79 & 34 & 113 \\
\hline & Total & 270 & 142 & 412 \\
\hline
\end{tabular}

Source: Author.

\section{Results and Implications}

\subsection{Results for institutional environment}

In order to be able to interpret the results regarding the teaching of entrepreneurial competence at the two universities in a structured manner, the first question that arises is: How many of the students have already taken part in a course in the subject entrepreneurship before the data collection?

At OTH Regensburg, 15 students stated in the first survey that they took part in an entrepreneurship course, and 50 stated so in the second survey. At VŠTE Budweis, the numbers were 42 students and 46, respectively.

This gives a total number of 153 students who had attended a corresponding course even before the corresponding data collection. 237 students $(\mathrm{N}=390)$ had not attended a relevant course previously. Figure 2 summarizes these findings.

\section{Participation in an Entrepreneurship Course}

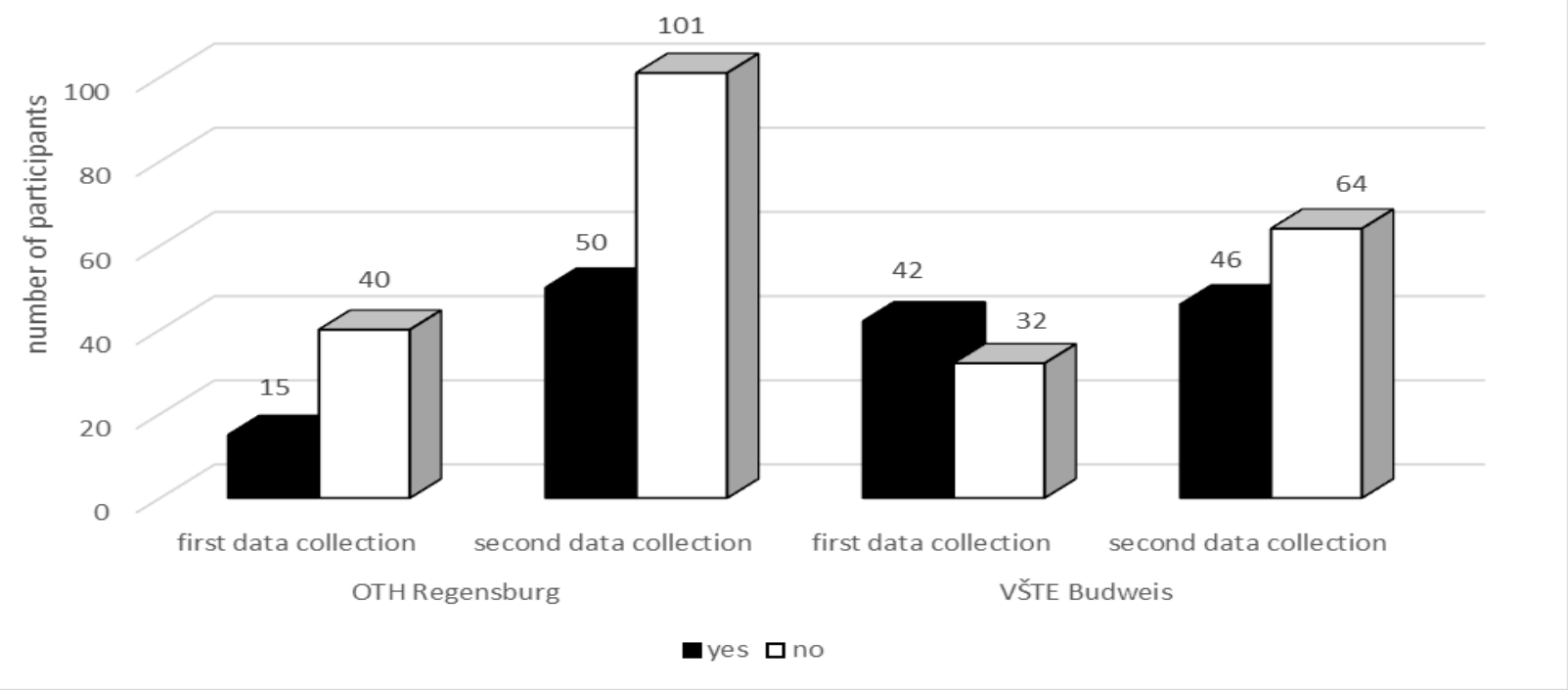

Figure 2. Participation in an entrepreneurship course

Source: Author. 
Figures 3 and 4 illustrate how the two universities are judged by the students with regard to the entrepreneurial environment and the promotion of entrepreneurial competence.

The answers could be given on a Likert scale from 1 to 7.

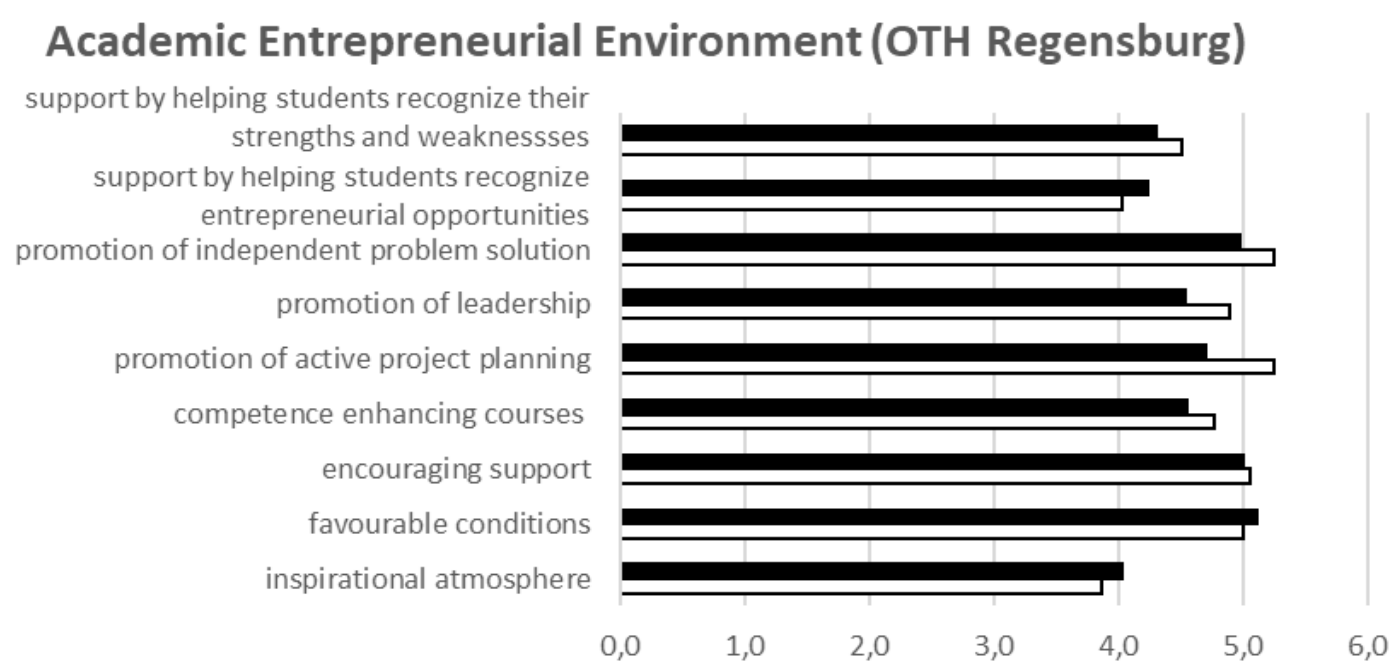

OTH Regensburg second data collection

口ОТн Regensburg first data collection

Figure 3. Academic entrepreneurial environment at OTH Regensburg

Source: Author.

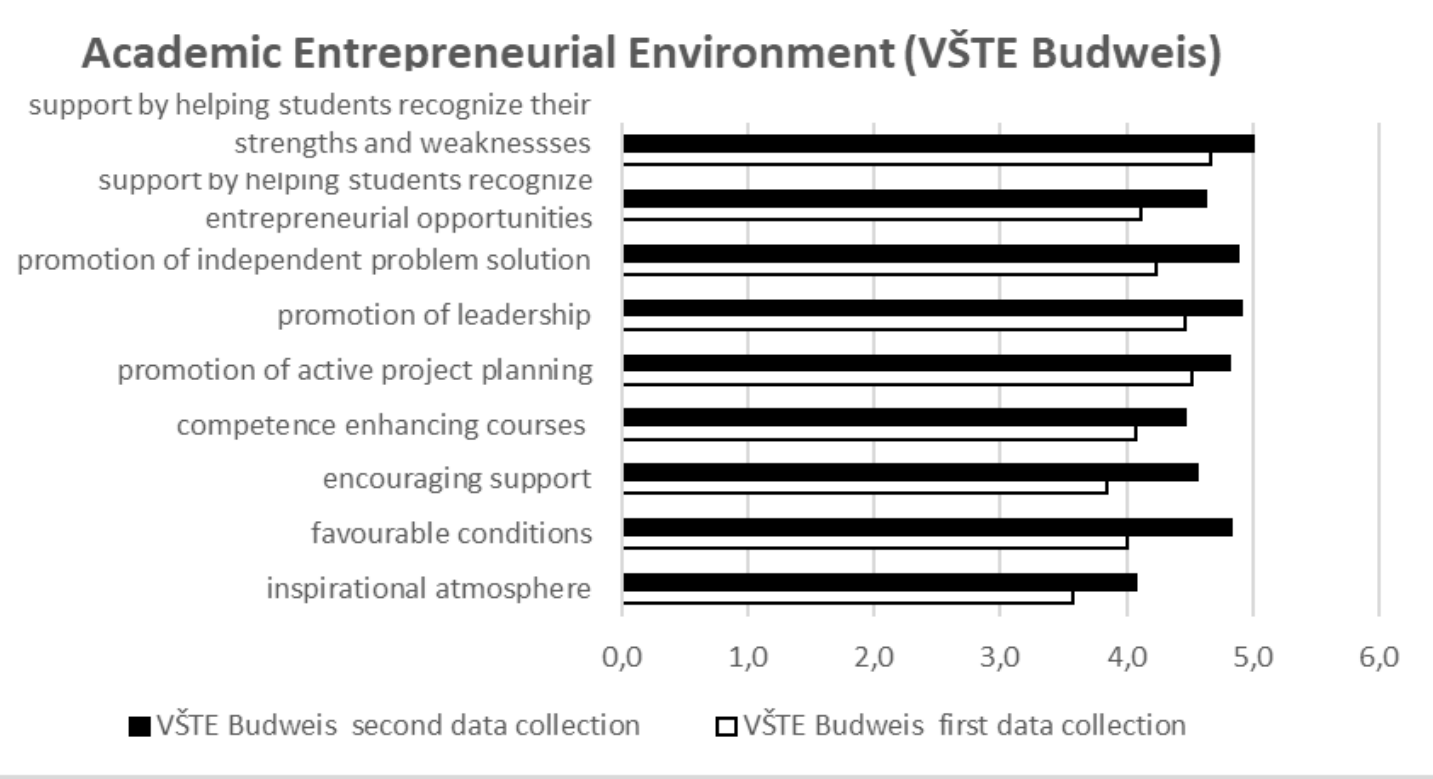

Figure 4. Academic entrepreneurial environment at VŠTE Budweis

Source: Author.

In order to promote the entrepreneurial environment after the first data collection at both institutes, an online course with teaching content on entrepreneurship was created. In addition, several conferences on entre- and intrapreneurship were organized and various professional articles and monographs published between the study periods. The teachinglearning methods were also further adapted. The following section on the implications for education seeks to explain in detail how even more intention-based teaching can contribute to the promotion of entrepreneurial competence in the future.

Firstly, the data obtained from the two investigation periods will be further interpreted. With regards to the entrepreneurial environment at the institutes, it is noticeable that in the second survey that all the factors surveyed at VŠTE Budweis were rated higher than at the beginning of the project in 2017 . This is evidenced especially by the higher ratings for the factors "promotion of independent problem solving" ("The lectures/offers at my institution contribute to me working independently on problems"), "encouraging support" ("At my institution, students are encouraged to become 
entrepreneurs") and "favorable conditions" ("At my institution there are favourable conditions for becoming a founder and, as a consequence, an entrepreneur").

At OTH Regensburg, the changes are less noticeable. However, positive trends can be seen in the factors "favorable conditions" and "inspirational atmosphere" ("The atmosphere at my institution inspires me to develop business ideas for my own company"). The factor "promotion of active project planning" ("The lectures/offers at my institution promote my ability to actively plan and implement projects") was rated worse during the second survey. In this respect, however, it is important to point out the problem of two different spot checks (cf. methodology). During the second survey, different students were interviewed than in the initial measurement. Depending on the subjective perception, there may therefore be certain distortions when making a comparison.

\subsection{Results for entrepreneurial intentions}

Entrepreneurial intentions, both firm and seriously considered, were also recorded and evaluated with the help of the input measurement. The intention to found one's own company (entrepreneurial intention) allows for quite good estimations of the founding intentions across the two investigation periods (cf. Figures 5 and 6 ).

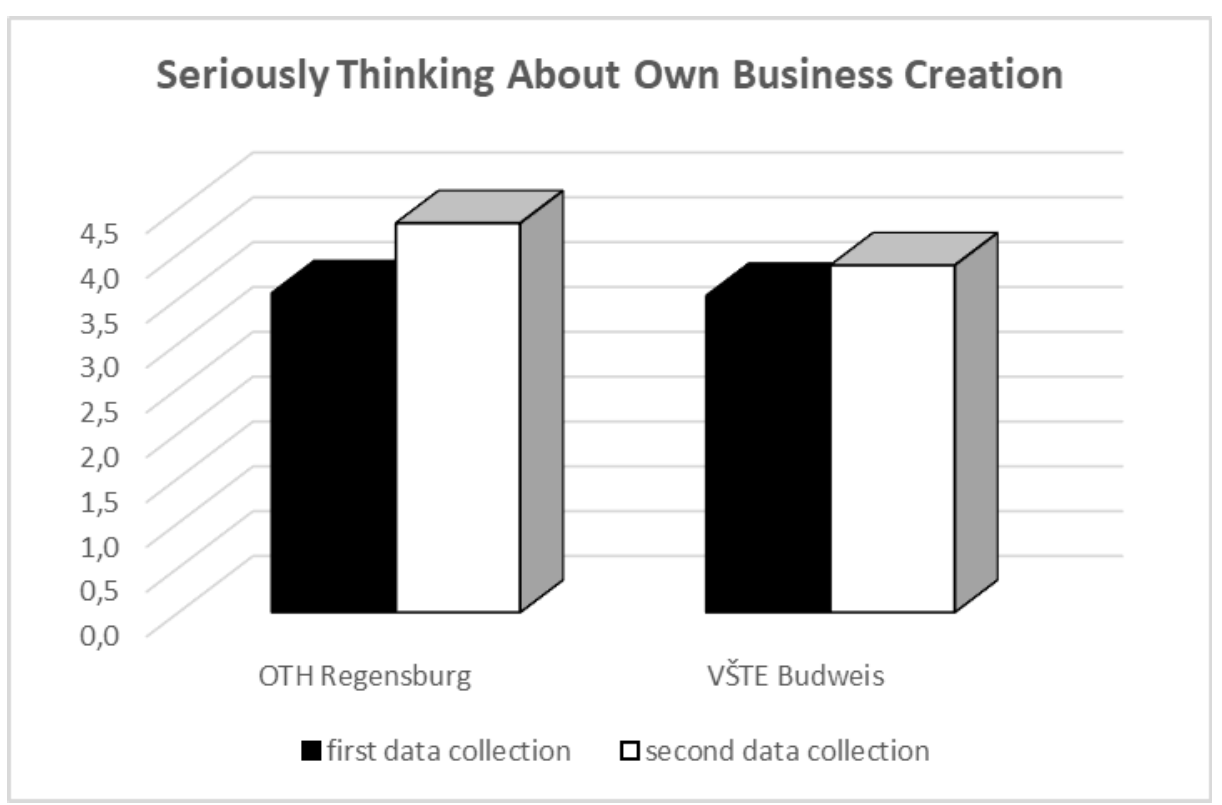

Figure 5. Seriously thinking about own business creation

Source: Author.

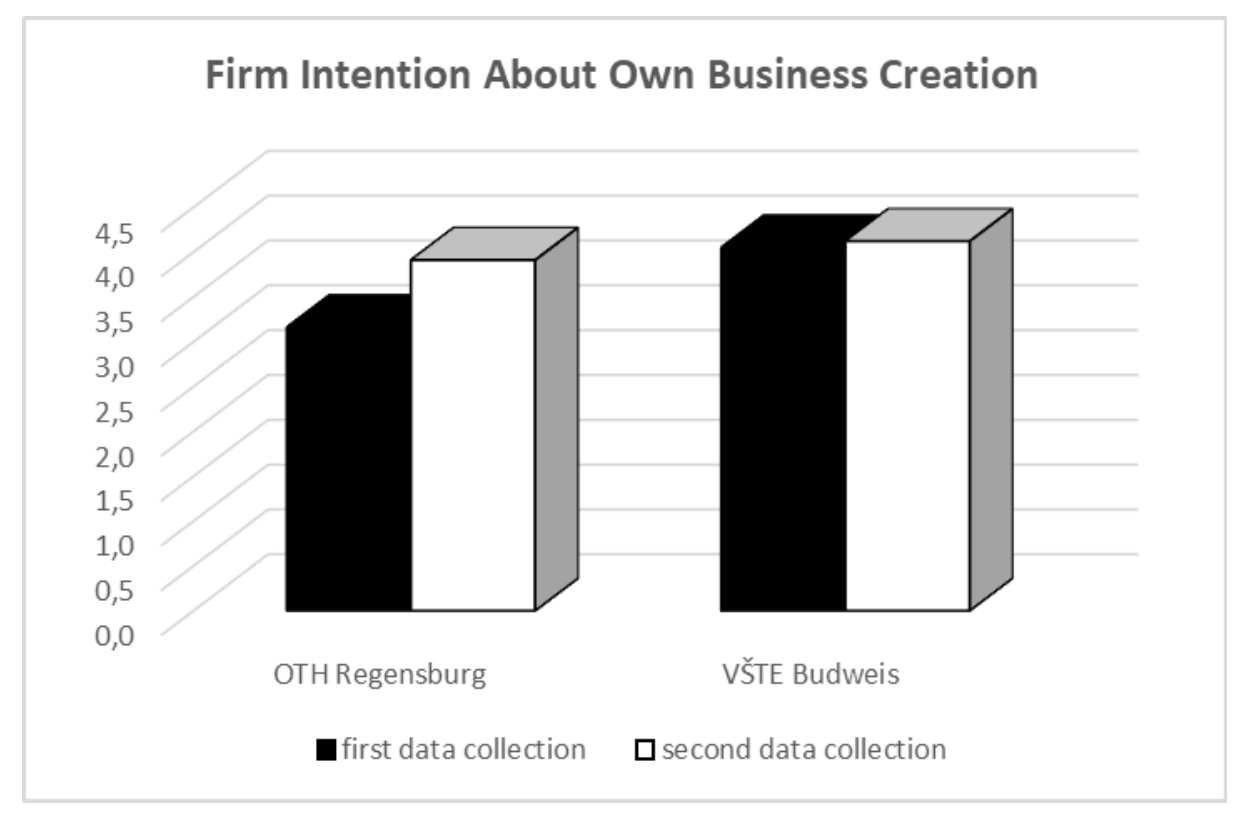

Figure. 6. Firm intention about own business creation

Source: Author. 
Looking at the two intention-based items "I have already seriously considered setting up or taking over a company" (cf. Figure 4) and "I have the firm intention of setting up or taking over a company one day", it is clear that the indicated intentions are higher at both institutes in the second survey. However, at OTH Regensburg, the entrepreneurial intention is significantly higher than at the VŠTE Budweis.

On the basis of the above findings, it can be concluded that the confidence in one's own entrepreneurial competence is more clearly visible among the students in the second survey than in the first.

\subsection{Results for entrepreneurial competence}

With regards to entrepreneurial competence, the students' knowledge and skills can be interpreted from the first and second surveys. The following two illustrations provide a corresponding group comparison of the two surveys at OTH Regensburg (cf. Figure 7) and at VŠTE Budweis (cf. Figure 8).

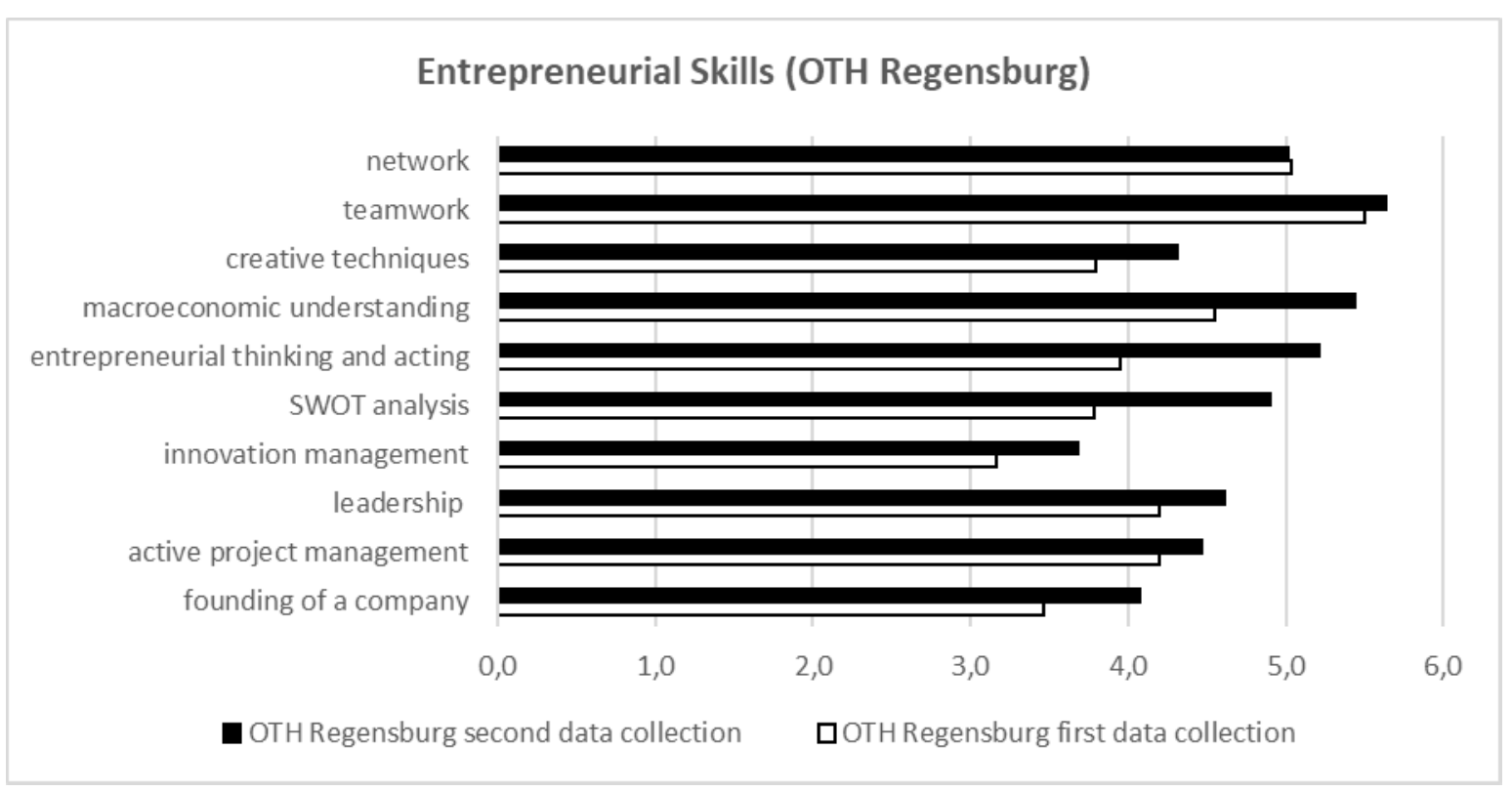

Figure 7. Entrepreneurial skills - OTH Regensburg

Source: Author.

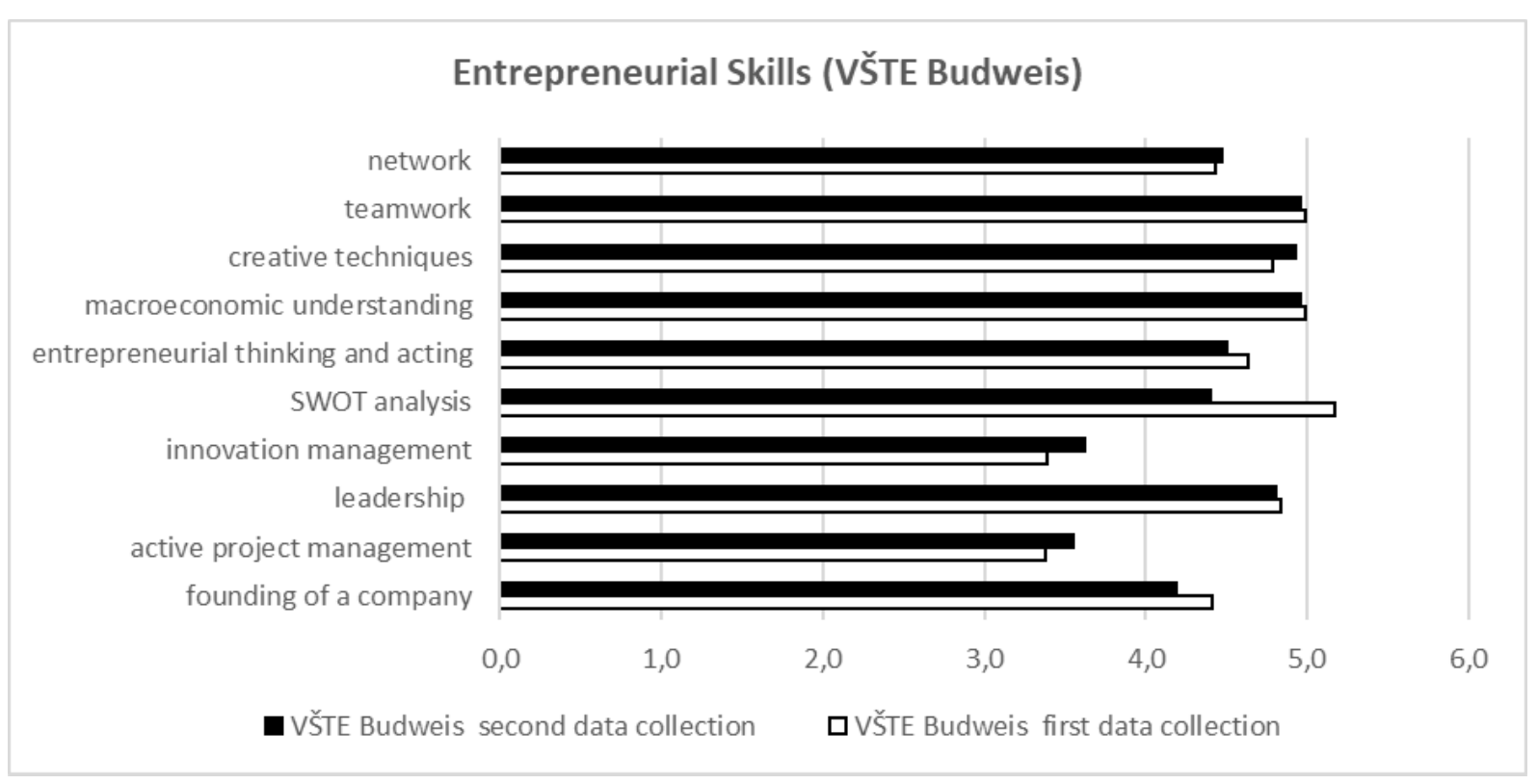

Figure 8. Entrepreneurial skills - VŠTE Budweis

Source: Author.

The students of OTH Regensburg assessed almost all factors related to their entrepreneurial knowledge and skills more highly in the second survey than in the first. This is particularly true in the case of "macroeconomic understanding", "entrepreneurial thinking and acting" and the implementation of the "SWOT analysis". At VŠTE Budweis, however, the 
differences between the two surveys are less clear. Knowledge of the "SWOT analysis" is much weaker, whereas that of "innovation management" and "active project management" are assessed better. However, the values are in the middle segment with an average value of 4 on a Likert scale of 1 to 7 . In order to be able to promote entrepreneurial knowledge and (cognitive) skills, but also the (psychological) characteristics and skills even more specifically in the future, it seems logical to adapt the teaching to the entrepreneurial intentions of the students. The following section shows which activating elements can be used appropriately in entre- and intrapreneurship education.

\subsection{Implications for education}

Direct implications for entre- and intrapreneurship education can be deduced from the large-scale study (author's dissertation) and the descriptive analysis on which it is based. In order to be able to adapt the teaching to the students, two questions arise: Which entrepreneurial intentions, both psychological and cognitive aspects thereof, are important individually or within a group? Which learning environments should be chosen to promote entrepreneurial competence in a holistic way?

In order to answer the first question, the existing findings suggest an assessment of needs is required. This assessment compares the target values of the ideally typical expression of entrepreneurs and intrapreneurs to the actual values of the input measurement, while differentiating between entrepreneurial and intrapreneurial intentions. In order to answer the second question, a suitable teaching-learning setting must be chosen, taking into account the results of the target-actual comparison. This should address the identified needs. In addition, it is advisable to go as far as possible beyond the traditional transmission of knowledge. Although lectures through front-line teaching allow for the transmission of factual knowledge, they do not activate students. In addition to technical competence, it is also recommended to promote methodological and social competence within the framework of holistic entrepreneurial competence. Methodological competence can, for example, be introduced into teaching by means of problem-solving approaches and social competence by means of techniques of cooperation and communication [22-23]. Figure 9 shows which elements of entrepreneurship and intrapreneurship teaching activate students. Since these elements are suitable in different ways for entrepreneurship or intrapreneurship education, different positions have been chosen in the space between the two fields of study.

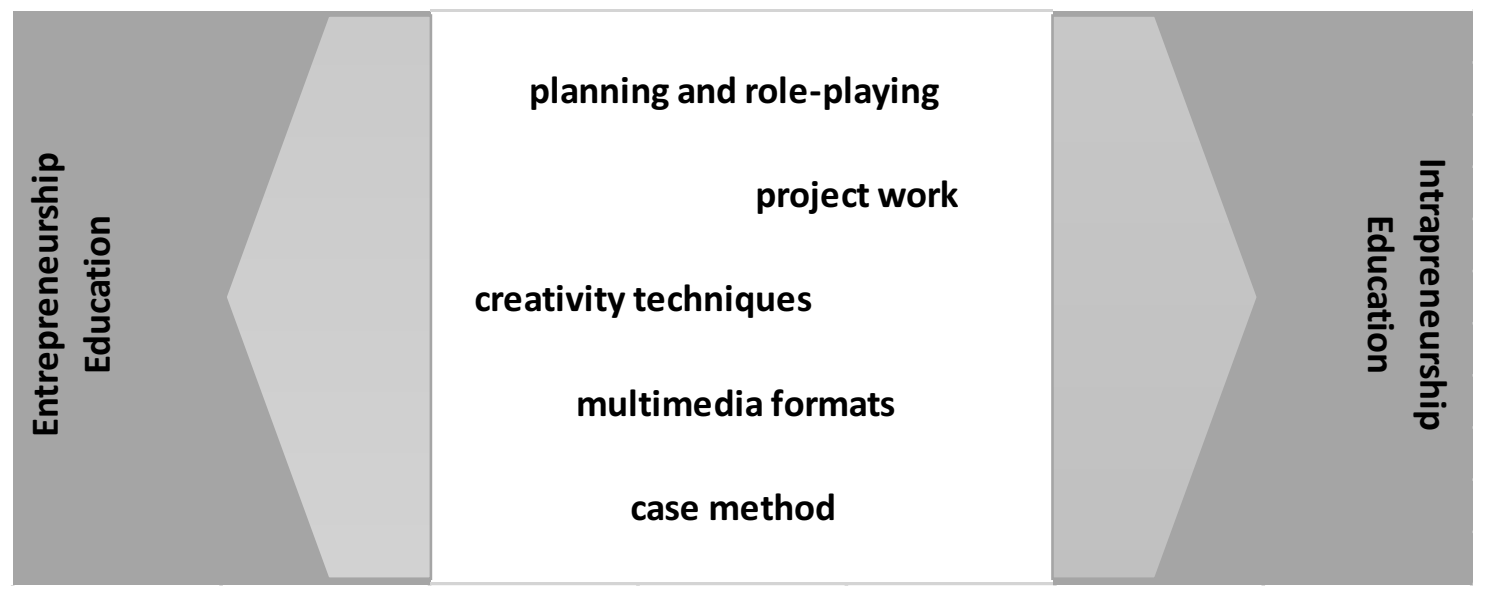

Figure 9. Activating elements in entrepreneurship and intrapreneurship education

Source: Author.

These activating elements within entrepreneurship and intrapreneurship teaching, which can be expanded as desired, can serve to promote holistic entrepreneurial competence (entrepreneurial competence). Planning and role-playing games have a strong relationship to methodological and social competence, while the case study method and multimedia formats serve more to convey and apply factual knowledge. These three methods appear equally interesting for entre- and intrapreneurship education. On the other hand, project work is suited to the targeted promotion of social competence by means of interdisciplinary teams working communicatively together on a task. Initial findings suggest that social competence is in turn appropriate in intrapreneurship teaching. Entrepreneurship teaching, on the other hand, often requires methodological competence, since founders are often decision-makers and creators. Here, problem-solving approaches such as the use of creativity techniques, seem to be useful [24-25].

After completing entrepreneurship and/or intrapreneurship education, an evaluation measurement may be carried out to verify the success of the activating elements used. Within the context of the author's dissertation, an evaluation model for the efficacy of competence promotion was created, which takes into account the theory of planned behavior according to Ajzen, as well as the proposed modification according to Rauch and Hulsink. Such "post-evaluations" (after apprenticeship) makes it possible to compare current entrepreneurial competence and entrepreneurial intentions with the ideal-typical expression in entrepreneurship and intrapreneurship. Following this evaluation measurement, it may again be possible to integrate activating elements into further teaching and new action strategies to promote and instigate 
entrepreneurial intentions. In this way, students with a concrete business idea could be given targeted start-up advice in addition to their teaching. For potential intrapreneurs, an internship semester in innovation management would again be conceivable. The aim of all such interventions should be not only to promote entrepreneurial intentions and entrepreneurial skills, but also to ensure that the intentions ultimately translate into concrete entrepreneurial behavior.

In order to be able to assess the immediate success of teachers, it also seems logical to undertake an evaluation before ("pre-evaluation") and after the courses ("post-evaluation"). A recurring evaluation of potential entrepreneurs and intra-entrepreneurs could highlight even better the impact of entrepreneurship and intra-entrepreneurship teaching on entrepreneurial intentions and ultimately on entrepreneurial behavior. The teacher's success could then also be derived.

\section{Conclusion}

An initial measurement of the entrepreneurial intentions and the entrepreneurial competence seems necessary in order to be able to adapt the teaching even more to the needs of the students. Entrepreneurship and intrapreneurship intentions can be distinguished, but they have one thing in common: to enable students to put ideas into practice by means of creativity, risk-taking and other attributes. Entrepreneurial competence has matured into an everyday competence that can be helpful in any life situation. The theory of planned behavior of Ajzen [11] and current modifications in entrepreneurship [15-19] makes it possible to better understand entrepreneurial intentions. On this basis, entrepreneurial competence entrepreneurial qualities, knowledge and skills - can be promoted holistically.

Using the questionnaire "Entrepreneurial Competence", which was developed as part of the author's dissertation, findings in the field of higher education at OTH Regensburg and VŠTE Budweis, as well as on entrepreneurial intentions and entrepreneurial competence were obtained from the two surveys conducted. At both institutes combined, 153 students have already taken part in an entrepreneurship course. Education in the entrepreneurial field was also rated as aboveaverage at both institutes. At VŠTE Budweis, the factors were rated much higher in the second survey than in the first. At OTH Regensburg, only minor changes were observed between the surveys. In August 2019, OTH Regensburg's students assessed their entrepreneurial knowledge and skills even more highly than in March 2017. VŠTE Budweis shows less marked differences in the cognitive aspects of entrepreneurial competence.

These descriptive results make it clear that an even stronger alignment of teaching to the needs of students by means of intention-based teaching-learning settings seems useful. The latter require, in particular, activating elements that meet the needs of the two intention groups. Depending on the type of intention, different elements within teaching can be applied that go beyond the classical transmission of knowledge. In order to promote holistic competence in practice (entrepreneurial competence), a wide range of activating elements can be used within entrepreneurship and intrapreneurship teaching, which are related to technical, methodological and social competence. These can be integrated into the teaching in a variety of ways, depending on their character. Thus, for example, case studies and multimedia formats are more suited to the transmission of factual knowledge (specialist competence), whilst project work has a strong connection to social competence and creativity techniques are increasingly connected to methodological competence. While planning, role-play, multimedia formats and case studies should be integrated into entre- and intrapreneurship education, project work, for example, seems better suited to intrapreneurship education because of its social component, whilst the teaching of creative techniques for entrepreneurship education is a probate means of promoting entrepreneurial competence. However, these activating elements can be expanded as desired. Depending on the focus, various elements can be selected within entre- and intrapreneurship education. While entrepreneurship teaching should probably focus on problem-solving approaches in the sense of imparting methodological competence in addition to specialist competence, intrapreneurship teaching should probably focus more on social competence in the sense of social leadership of innovation projects in addition to factual knowledge. However, such a systematization should not obscure the fact that entrepreneurs should also have social competence and intra-entrepreneurs should also have methodological competence in the sense of a holistic competence to act.

\section{Acknowledgement}

This article contains a partial output of the dissertation „Der Unternehmer in uns - Entwicklung einer Diagnostik der unternehmerischen Absichten zur Förderung der unternehmerischen Kompetenz im Entre- und Intrapreneurship“ ("The entrepreneur within us - development of a diagnostic tool for entrepreneurial intentions to promote entrepreneurial competence in entrepreneurship and intrapreneurship"). The dissertation is expected to be published in spring 2021. 


\section{References}

1. G. Pinchot, Intrapreneuring - Mitarbeiter als Unternehmer [Intrapreneuring - employees as entrepreneurs]. Wiesbaden: Gabler Verlag (1988)

2. G. Pinchot, Intrapreneuring. Longe Range Planning. 29(3), 405-411 (1996)

3. R. D. Hisrich, Entrepreneurship/Intrapreneurship. American Psychologist. 45(2), 209-222 (1990)

4. M. Bitzer, Intrapreneurship - Unternehmertum in der Unternehmung [Intrapreneurship - entrepreneurship in the company]. Stuttgart, Zürich: Schäffer, Verlag für Wirtschaft und Steuern (1991)

5. R. Wunderer, H. Bruch, Umsetzungskompetenz: Diagnose und Förderung in Theorie und Unternehmenspraxis [Implementation skills: Diagnosis and support in theory and business practice]. München: Vahlen (2000)

6. Europäische Kommission, Schlüsselkompetenzen für lebensbegleitendes Lernen - Ein europäischer Referenzrahmen [Key Competences for Lifelong Learning - A European Framework of Reference]. Luxemburg: Amt für amtliche Veröffentlichungen der Europäischen Gemeinschaften (2007)

7. J. Erpenbeck, L. von Rosenstiel, Handbuch Kompetenzmessung. Erkennen, verstehen und bewerten von Kompetenzen in der betrieblichen, pädagogischen und psychologischen Praxis [Competency measurement manual. Recognizing, understanding and evaluating competencies in operational, educational and psychological practice]. Stuttgart: Schäffer-Poeschel Verlag (2007)

8. G. F. Müller, Unternehmerische Kompetenz [Entrepreneurial competence]. In W. Sarges. Management-Diagnostik. Hogrefe Verlag, Göttingen, 467-473 (2013)

9. G. F. Müller, M. Sauerland, G. Raab, Wir alle sind Unternehmer! - Die Psychologie erfolgreicher Gründung und Führung von Unternehmen [We are all entrepreneurs! - The psychology of successful business creation and management]. Hamburg: Windmühle Verlag (2016)

10. I. Ajzen, From intentions to actions. A theory of planned behavior. In J. Kuhl, J. Beckmann. Action control: From cognition to behaviour. New York: Springer-Verlag, 11-39 (1985)

11. I. Ajzen, The theory of planned behavior. Organizational Behavior \& Human Decision Processes. 50(2), 179-211 (1991)

12. I. Ajzen, Perceived behavioural control, self-efficacy, locus of control, and the theory of planned behaviour. Journal of Applied Social Psychology. 32(4), 665-683 (2002)

13. I. Ajzen, Attitudes, personality and behavior. Maidenhead. Berkshire: Open University Press, McGraw-Hill Education (2005)

14. I. Ajzen, The theory of planned behaviour is alive and well, and not ready to retire: a commentary on Sniehotta, Presseau, and Araujo-Soares. Health Psychology Review. 9(2), 131-137 (2015)

15. I. Ajzen, Reasoned Action in the Service of Goal Pursuit. Psychological Review. 126(5), 774-786 (2019)

16. I. Ajzen, M. Fishbein, S. Lohmann, D. Albarracin, The Influence of Attitudes on Behavior. Handbook of Attitudes. 1, 197-255 (2019)

17. F. La Barbera, I. Ajzen, Control Interactions in the Theory of Planned Behavior: Rethinking the Role of Subjective Norm. Europes Journal of Psychology. 16(3), 401-417 (2020)

18. M. Bosnjak, I. Ajzen, The Theory of Planned Behavior: Selected Recent Advances and Applications. Europes Journal of Psychology. 16(3), 352-356 (2020)

19. A. Rauch, W. Hulsink, Putting entrepreneurship education where the intention to act lies: An investigation into the impact of entrepreneurship education on entrepreneurial behavior. Academy of Management Learning \& Education. 14(2), 187-204 (2015)

20. H. Bergmann, S. Golla, Unternehmertum an Hochschulen in Deutschland. Ergebnisse des Global University Entrepreneurial Spirit Students' Survey 2016 [Entrepreneurship at universities in Germany. Results of the Global University Entrepreneurial Spirit Students 'Survey 2016]. St. Gallen, Fulda: Universität St. Gallen, Hochschule Fulda (2016)

21. B. Rammstedt, O. P. John, Kurzversion des Big Five Inventory (BFI-K): Entwicklung und Validierung eines ökonomischen Inventars zur Erfassung der fünf Faktoren der Persönlichkeit [Short version of the Big Five Inventory 
(BFI-K): Development and validation of an economic inventory to record the five factors of personality]. Diagnostica. 51(4), 195-206 (2005)

22. H. Grüner, Entrepreneurial Learing - Ist eine Ausbildung zum Unternehmertum möglich? [Entrepreneurial Learing - Is entrepreneurship training possible?]. Zeitschrift für Berufs- und Wirtschaftspädagogik. 5, 485-509 (1993)

23. H. Klandt, Entrepreneurship spielend lernen: Erfahrungen beim Einsatz eines Computerplanspiels zur Vermittlung der mittelständischen Unternehmerrolle [Learning entrepreneurship through play: experience in using a computer simulation game to convey the role of medium-sized entrepreneur]. In G. Faltin, S. Ripsas, J. Zimmer. Entrepreneurship: Wie aus Ideen Unternehmen werden. München: C. H. Beck Verlag, 197-216 (1998)

24. H. Plattner, C. Meinel, U. Weinberg, Design Thinking: Innovation lernen - Ideenwelten öffnen. München: miWirtschaftsbuch, FinanzBuch Verlag GmbH, (2009)

25. R. Schulte, H. Klandt, Aus- und Weiterbildungsangebote für Unternehmensgründer und selbständige Unternehmer an deutschen Hochschulen [Training and further education offers for company founders and self-employed entrepreneurs at German universities]. Bonn: Bundesministerium für Bildung, Wissenschaft, Forschung und Technologie, (1996) 